\title{
The effect of a mixture of herbal essential oils or $\alpha$-tocopheryl acetate on performance parameters and oxidation of body lipid in broilers
}

\author{
N.A. Botsoglou ${ }^{1 \#}$, E. Christaki ${ }^{1}$, P. Florou-Paneri ${ }^{1}$, I. Giannenas ${ }^{1}$, G. Papageorgiou ${ }^{2}$ and \\ A.B. Spais ${ }^{1}$ \\ ${ }^{1}$ Laboratory of Animal Nutrition, School of Veterinary Medicine, and \\ ${ }^{2}$ Laboratory of Biological Chemistry, School of Medicine, Aristotle University, 54006 Thessaloniki, Greece
}

\begin{abstract}
Performance parameters and oxidation of body lipids of broiler chickens were investigated when their diet was supplemented with a commercial preparation of essential oils (Apacox) derived from selected herbs. One hundred and twenty day-old Cobb-500 female chicks were divided into four groups with three replicates each. One group received the basal diet, the control. The three experimental diets consisted of the basal diet to which either $200 \mathrm{mg} \alpha$-tocopheryl acetate $/ \mathrm{kg}$ (Toc200 group), Apacox at $0.5 \mathrm{~g} / \mathrm{kg}$ (Apa0.5 group) or Apacox at $1.0 \mathrm{~g} / \mathrm{kg}$ diet (Apa1.0 group) was added. At the end of the 42 day feeding period there were no differences in initial and final body weights, daily weight gains, daily feed intakes and feed conversion ratios between treatments, and no mortalities were recorded. It is concluded that the mixture of herbal essential oils exerted no growth-promoting effect when incorporated in the chicken diet. The progress of lipid oxidation was assessed in raw and heat treated breast and thigh muscle at $0,3,6$ and 9 days of refrigerated storage at $4{ }^{\circ} \mathrm{C}$. Results showed that Apacox retarded lipid oxidation in both raw and heat treated breast and thigh muscles at all time points, with the supplementation level of $1.0 \mathrm{~g} / \mathrm{kg}$ diet being more effective in retarding lipid oxidation than the $0.5 \mathrm{~g}$ Apacox $/ \mathrm{kg}$ treatment. The retardation offered by Apacox was, however, inferior to that exhibited by $\alpha$-tocopheryl acetate supplementation. Raw and heat treated thigh muscle samples were more susceptible to oxidation compared to breast muscle, although the latter contained $\alpha$-tocopherol at markedly lower concentrations.
\end{abstract}

Keywords: Essential oil mixture, herbs, performance, oxidative stability, $\alpha$-tocopherol acetate, chickens ${ }^{\#}$ Corresponding author. E-mail: bots@vet.auth.gr

\section{Introduction}

Antibiotic feed additives have long been used as growth promoters. However, concern has been expressed about the potential development of antibiotic resistant bacteria (Botsoglou \& Fletouris, 2001). As a result, the animal feed industry is under increasing pressure from consumer associations to reduce the use of antibiotics in feeds and to find alternative feed additives.

Due to their antimicrobial properties, essential oils derived from several spices and herbs could be used as alternative feed additives in animal nutrition. However, most of the published data focused on in vitro investigations (Hammer et al., 1999; Dorman \& Deans, 2000; Lambert et al., 2001; Ultee et al., 2002). Only recently there have been some reports of in vivo studies examining the effect of dietary essential oil supplementation on growth performance of chickens (Hertrampf, 2001; Botsoglou et al., 2002a; Alcicek et al., 2003; Giannenas et al., 2003; Lee et al., 2003) and turkeys (Papageorgiou et al., 2003). Alcicek et al. (2003) reported that diet supplementation with an essential oil combination from six herbs including oregano, laurel, sage, myrtle, fennel and citrus improved chicken performance. In agreement with these results, other authors (Basset, 2000; Hertrampf, 2001) found that essential oil from oregano could improve the performance of chickens when administered through the drinking water at 150 or $300 \mathrm{~mL} / \mathrm{ton}$. In contrast, Lee et al. (2003) reported that diet supplementation with an essential oil preparation (Crina Poultry, Akzo Nobel, Crina S.A., Gland, Switzerland) did not improve the growth performance of broiler chickens, whilst Botsoglou et al. (2002a) and Papageorgiou et al. (2003) reported that dietary supplementation of oregano essential oil at levels of 50 or $100 \mathrm{mg} / \mathrm{kg}$ to chickens, and at levels of 100 or $200 \mathrm{mg} / \mathrm{kg}$ to turkeys, respectively, had no beneficial effect on growth performance. Despite these inconsistent results, the antimicrobial properties shown by herbal essential oils suggest that their use in poultry production might offer a promising potential as alternatives to antibiotic growth promoters.

In addition to their antimicrobial properties, essential oils can also exhibit antioxidative properties in the body (Nakatani, 1997; Dapkevicious et al., 1998; Zheng \& Wang, 2001; Exarchou et al., 2002). Essential 
oils from many herbs and spices have been tested for their potential to extend the shelf-life of foods when added exogenously (Wada \& Fang, 1992; Tsimidou et. al., 1995; Abdalla \& Roozen, 2001). Supplementation of poultry diets with essential oils has also been studied as a simple and convenient strategy to introduce natural antioxidants into meat (Botsoglou et al., 2002a). Dietary control of lipid oxidation in meat through introduction of natural antioxidants that are harmless to consumers would be of particular value to the poultry meat industry. Recent in vivo studies have shown that essential oils of rosemary and sage (Lopez-Bote et al., 1998), tea (Tang et al., 2000; 2001), and oregano (Botsoglou et al., 2002b; 2003a, b, c; Papageorgiou et al., 2003) could all increase the antioxidant content of chicken and turkey tissues when incorporated in their diets.

The first objective of the present study was to examine the effect of diet supplementation with a mixture of essential oils from selected herbs on growth performance of broiler chickens. The second objective was to investigate whether this supplementation could have an effect on the antioxidant content and rate of oxidation in chicken breast and thigh tissues and to compare this effect with that exhibited by supplementation of the diet with $\alpha$-tocopheryl acetate. The herbs used in this study as source of essential oils were agrimony or marigold (Agrimonia eupatoria), Echinacea or purple coneflower (Echinacea angustifolia), black currant (Ribes nigrum) and yellow bark (Cinchona succirubra).

\section{Materials and Methods}

One hundred and twenty female day-old Cobb-500 broiler chicks, purchased from a local commercial hatchery, were weighed and randomly assigned to four groups of 30 birds each. Each group was further separated into three subgroups (replicates) of 10 birds each. Each of the 12 subgroups was housed in a separate floor pen equipped with wood shaving litter and an infrared lamp. The stocking density of each pen was 15 birds $/ \mathrm{m}^{2}$. Temperature was $32{ }^{\circ} \mathrm{C}$ during week one, $28{ }^{\circ} \mathrm{C}$ during week two, and $23{ }^{\circ} \mathrm{C}$ thereafter. The lighting regimen provided $22 \mathrm{~h}$ of continuous light per day. Birds were vaccinated against Newcastle disease and infectious bronchitis on the $10^{\text {th }}$ day of age and against Gumboro disease on 17 days of age.

Birds within the control group (Control) were given a commercial basal diet supplemented with 30 $\mathrm{mg} \alpha$-tocopheryl acetate $/ \mathrm{kg}$, derived from a premix (BASF, Germany). The ingredient and the nutrient composition of the basal diet are presented in Table 1. The remaining three experimental diets were based on the basal diet, but were further supplemented with an additional $200 \mathrm{mg} \alpha$-tocopheryl acetate $/ \mathrm{kg}$ (Toc200), or Apacox at $0.5 \mathrm{~g} / \mathrm{kg}$ diet (Apa0.5) or $1.0 \mathrm{~g} / \mathrm{kg}$ diet (Apa1.0). Apacox is a naturally derived commercial preparation that is registered and licensed as a nutrition enhancer (APA-CT s.r.l. Italy). It contains a mixture of essential oils of the plants Agrimonia eupatoria, Echinacea angustifolia, Ribes nigrum and Cinchona succirubra. Feed in mash form and drinking water were offered ad libitum. Broilers were weighed at fixed intervals of one week and feed intakes per pen were recorded. Feed conversion ratios at 42 days of age were calculated by dividing feed intake to weight gain. Mortality was recorded daily.

At 42 days of age all birds were slaughtered under commercial conditions. Individual carcasses from three birds per subgroup were immediately trimmed for breast (pectoralis major) and thigh (biceps femoris) muscles by removing skin, bones and connective tissue. Following trimming, breast and thigh muscle samples per subgroup were separately pooled, vacuum packaged and stored at $25{ }^{\circ} \mathrm{C}$ until required for lipid oxidation studies and analysis of $\alpha$-tocopherol.

To study the effect of the dietary treatments on lipid oxidation, pooled breast and thigh muscle samples were thawed overnight at $4{ }^{\circ} \mathrm{C}$, and, then, separately minced through $5 \mathrm{~mm}$ plates using a domestic rust-free steel meat mincer. Samples from the minced muscles were wrapped in transparent oxygenpermeable polyvinyl chloride film, and placed in a non-illuminated refrigerated cabinet at $4{ }^{\circ} \mathrm{C}$ for a total of nine days. The progress of lipid oxidation was determined on days $0,3,6$ and 9, based on malondialdehyde (MDA) concentration. A similar experiment was carried out on heat treated samples. For this purpose, minced raw breast and thigh samples were placed in Ziplog plastic bags and placed in a water bath at $85{ }^{\circ} \mathrm{C}$. After $30 \mathrm{~min}$ of heating, the samples were cooled under tap water, placed in a non-illuminated refrigerated cabinet at $4{ }^{\circ} \mathrm{C}$, and submitted to MDA assay on days $0,3,6$ and 9 of storage for assessing the extent of lipid oxidation. 
Table 1 Ingredients and composition of the basal diet (Control), and diets supplemented with either a mixture of herbal essential oils at levels of $0.5 \mathrm{~g} / \mathrm{kg}$ (Apa0.5) or $1.0 \mathrm{~g} / \mathrm{kg}$ (Apa1.0), or $200 \mathrm{mg} / \mathrm{kg} \alpha$ tocopheryl acetate (Toc200) (as fed basis)

\begin{tabular}{|c|c|c|c|c|}
\hline & \multicolumn{4}{|c|}{ Composition of experimental diets $(\mathrm{g} / \mathrm{kg})$} \\
\hline & Control & Apa0.5 & Apa1.0 & Toc200 \\
\hline \multicolumn{5}{|l|}{ Ingredients } \\
\hline Wheat & 610.0 & 610.0 & 610.0 & 610.0 \\
\hline Soya bean meal & 280.0 & 280.0 & 280.0 & 280.0 \\
\hline Herring meal & 20.0 & 20.0 & 20.0 & 20.0 \\
\hline Soya bean oil & 40.0 & 40.0 & 40.0 & 40.0 \\
\hline Maize gluten feed & 17.9 & 17.4 & 16.9 & 17.6 \\
\hline Limestone & 12.0 & 12.0 & 12.0 & 12.0 \\
\hline Dicalcium phosphate & 6.0 & 6.0 & 6.0 & 6.0 \\
\hline Salt & 3.0 & 3.0 & 3.0 & 3.0 \\
\hline Sodium bicarbonate & 1.5 & 1.5 & 1.5 & 1.5 \\
\hline Biolysine-BASF & 2.5 & 2.5 & 2.5 & 2.5 \\
\hline DL-Methionine & 2.0 & 2.0 & 2.0 & 2.0 \\
\hline Vitamins premix* & 2.0 & 2.0 & 2.0 & 2.0 \\
\hline Trace mineral premix $* *$ & 2.0 & 2.0 & 2.0 & 2.0 \\
\hline Choline chloride $50 \%$ & 0.8 & 0.8 & 0.8 & 0.8 \\
\hline Phytase-BASF & 0.1 & 0.1 & 0.1 & 0.1 \\
\hline Arabinoxylanases+glucanases-BASF & 0.2 & 0.2 & 0.2 & 0.2 \\
\hline$\alpha$-Tocopheryl acetate-BASF (50\%) & 0.0 & 0.0 & 0.0 & 0.4 \\
\hline Apacox & 0.0 & 0.5 & 1.0 & 0.0 \\
\hline \multicolumn{5}{|l|}{ Chemical analysis $* * *$} \\
\hline Crude protein $(\mathrm{g} / \mathrm{kg})$ & 221 & 223 & 222 & 224 \\
\hline Fat $(\mathrm{g} / \mathrm{kg})$ & 62 & 62 & 61 & 61 \\
\hline Crude fibre $(\mathrm{g} / \mathrm{kg})$ & 38 & 37 & 39 & 38 \\
\hline Ash (g/kg) & 5.1 & 5.2 & 4.9 & 5.1 \\
\hline \multicolumn{5}{|l|}{ Calculated analysis } \\
\hline Calcium $(\mathrm{g} / \mathrm{kg})$ & 9 & 9 & 9 & 9 \\
\hline Phosphorus $(\mathrm{g} / \mathrm{kg})$ & 6 & 6 & 6 & 6 \\
\hline Lysine $(\mathrm{g} / \mathrm{kg})$ & 13 & 13 & 13 & 13 \\
\hline Methionine + Cystine $(\mathrm{g} / \mathrm{kg})$ & 10 & 10 & 10 & 10 \\
\hline Metabolisable energy $(\mathrm{MJ} / \mathrm{kg})$ & 13.1 & 13.1 & 13.1 & 13.1 \\
\hline
\end{tabular}

*Supplying / kg feed: $3.44 \mathrm{mg}$ all-trans retinol acetate; $87.5 \mu \mathrm{g}$ cholecalciferol; $30 \mathrm{mg} \alpha$-tocopheryl acetate; $5 \mathrm{mg}$ menadione sodium bisulphite; $3 \mathrm{mg}$ thiamine hydrochloride; $4 \mathrm{mg}$ riboflavin; $6 \mathrm{mg}$ pyridoxine hydrochloride; $0.02 \mathrm{mg}$ cyanocobalamin; $60 \mathrm{mg}$ niacin; $15 \mathrm{mg}$ pantothenic acid; $1.5 \mathrm{mg}$ folic acid; $0.25 \mathrm{mg}$ biotin; $10 \mathrm{mg}$ ascorbic acid

**Supplying / kg feed: $100 \mathrm{mg} \mathrm{Zn;} 120 \mathrm{mg} \mathrm{Mn;} 20 \mathrm{mg} \mathrm{Fe} ; 15 \mathrm{mg} \mathrm{Cu} ; 0.2 \mathrm{mg} \mathrm{Co} ; 1 \mathrm{mg} \mathrm{I} ; 0.3 \mathrm{mg} \mathrm{Se}$

***According to AOAC (1984)

Determination of MDA, the compound used as an index of lipid peroxidation, was carried out by a selective third-order derivative spectrophotometric method (Botsoglou et al., 1994). In brief, $1 \mathrm{~g}$ samples were thoroughly homogenised (Polytron homogenizer, PCU, Switzerland) in the presence of $8 \mathrm{~mL}$ of aqueous trichloroacetic acid $(50 \mathrm{~g} / \mathrm{L})$ and $5 \mathrm{~mL}$ of butylated hydroxytoluene in hexane $(8 \mathrm{~g} / \mathrm{L})$ and the mixture was centrifuged. The top layer was discarded and a $2.5 \mathrm{~mL}$ aliquot from the bottom layer was mixed with $1.5 \mathrm{~mL}$ of aqueous 2-thiobarbituric acid $(8 \mathrm{~g} / \mathrm{L})$ to be further incubated at $70^{\circ} \mathrm{C}$ for $30 \mathrm{~min}$. Following incubation, the mixture was cooled to room temperature and submitted to conventional spectrophotometry (Shimadzu, Model UV-160A, Tokyo, Japan) in the range of 400-650 $\eta \mathrm{m}$. Third-order derivative spectra were produced by digital differentiation of the normal spectra using a derivative wavelength difference setting of $21 \mathrm{~nm}$. The concentration of MDA ( $\eta \mathrm{g} / \mathrm{g}$ wet tissue) in samples was calculated on the basis of the height of the third-order derivative peak at $521.5 \mathrm{~nm}$ by referring to slope and intercept data of the computed 
least-squares fit of the standard calibration curve prepared, using 1,1,3,3-tetraethoxypropane. Butylated hydroxytoluene, 2-thiobarbituric acid, and 1,1,3,3-tetraethoxypropane, the precursor of MDA were obtained from Sigma Chemical Co. (St. Louis, MO) and trichloroacetic acid from Merck (Darmstadt, Germany).

Extraction of $\alpha$-tocopherol from breast and thigh muscle samples was carried out as described by Botsoglou et al. (1998). In brief, $0.5 \mathrm{~g}$ samples were homogenised (Polytron homogenizer, PCU, Switzerland) with $100 \mu \mathrm{L}$ of pyrocatechol solution and $5 \mathrm{~mL}$ of a saturated methanolic solution of $\mathrm{KOH}$, and the tubes were immersed in a bath at $80{ }^{\circ} \mathrm{C}$ for $15 \mathrm{~min}$. Following saponification, $5 \mathrm{~mL}$ hexane and $1 \mathrm{~mL}$ water were added to each tube, the mixtures were vortex-mixed, centrifuged at $2000 \mathrm{~g}$, and an aliquot of the upper phases was evaporated to dryness to be further reconstituted in methanol and submitted to liquid chromatographic analysis (Shimadzu, Model 6AV, Tokyo, Japan). Liquid chromatography was carried out according to Sheehy et al. (1994). The packing material of the chromatographic column $(250 \mathrm{x} 4.6 \mathrm{~mm})$ was nucleosil $\mathrm{C}_{18}, 5 \mathrm{~mm}$, and the mobile phase consisted of methanol and water $(97: 3, \mathrm{v} / \mathrm{v})$ that delivered at a flow rate of $2 \mathrm{~mL} / \mathrm{min}$. A fluorimetric detector set at excitation wavelength of $290 \mathrm{~nm}$ and emission wavelength of $330 \mathrm{~nm}$ monitored the $\alpha$-tocopherol peak that was quantified on the basis of a calibration curve. The $\alpha$-Tocopherol was obtained from Sigma Chemical Co. (St. Louis, MO) and pyrocatechol from Merck (Darmstadt, Germany). All other reagents and solvents used, were analytical-grade.

Data on body weight, weight gain, feed intake and feed conversion ratios were subjected to analysis of variance (ANOVA) in the general linear model using the SPSS 10.05 statistical package (SPSS Ltd., Woking, Surrey, UK). The Bartlett's test was applied to test the homogeneity of the variances. The development of MDA in samples during storage was analyzed by a two-way analysis of variance, fixed effects model, including main effects of dietary treatment (4 levels) and time of storage (4 levels), and interaction between the two factors. Data on $\alpha$-tocopherol concentrations in samples were subjected to oneway analysis of variance. When significant treatment effects were disclosed at a probability of $\mathrm{P}<0.05$, the Tukey's test was applied to determine statistical differences between means (Steel \& Torrie, 1980).

\section{Results and Discussion}

The effect of dietary supplementation of a mixture of herbal essential oils on the performance of the chickens is presented in Table 2. There were no differences $(P>0.05)$ in initial or final body weights, daily weight gains or feed intakes between treatments. Significant treatment effects on any of these performance parameters were also not observed at 7, 14, 21, 28 and 35 days of age. No mortalities were recorded over the total feeding period. At 42 days of age there were also no differences $(\mathrm{P}>0.05)$ in feed conversion ratios between treatments. These results suggest that the mixture of herbal essential oils at 0.5 or $1.0 \mathrm{~g} / \mathrm{kg}$ did not exert a growth-promoting effect when incorporated in chicken diets.

Table 2 Performance of broiler chickens at 42 days of age in response to dietary supplementation with either a mixture of herbal essential oils at levels of $0.5 \mathrm{~g} / \mathrm{kg}$ (Apa0.5) or $1.0 \mathrm{~g} / \mathrm{kg}$ (Apa1.0), or with $200 \mathrm{mg} / \mathrm{kg} \alpha$ tocopheryl acetate (Toc200)

\begin{tabular}{lcccc}
\hline Performance & & \multicolumn{3}{c}{ Experimental groups } \\
parameters (1-42 days) & Control & Apa 0.5 & Apa1.0 & Toc200 \\
\hline & & & & \\
Initial weight, $\mathrm{g}$ & $39 \pm 1$ & $40 \pm 1$ & $39 \pm 1$ & $39 \pm 1$ \\
Final weight, $\mathrm{g}$ & $2266 \pm 62$ & $2225 \pm 48$ & $2252 \pm 66$ & $2291 \pm 74$ \\
Daily weight gain, $\mathrm{g}$ & $53 \pm 3$ & $52 \pm 2$ & $53 \pm 3$ & $54 \pm 4$ \\
Daily feed intake, $\mathrm{g}$ & $92 \pm 5$ & $92 \pm 4$ & $94 \pm 6$ & $94 \pm 5$ \\
Feed conversion ratio & $1.74 \pm 0.04$ & $1.77 \pm 0.06$ & $1.77 \pm 0.04$ & $1.74 \pm 0.03$ \\
\hline
\end{tabular}

${ }^{1}$ mean $(\mathrm{n}=3)$ values in rows do not differ $(\mathrm{P}>0.05)$

The observed lack of growth-promoting effect could not be compared with similar results in the literature since none has been reported where the same mixture of herbal essential oils was used. However, results on different essential oils or oil combinations have been reported, e.g. Lee et al. (2003) found that the dietary supplementation with another mixture of essential oils (Crina S.A., Gland, Switzerland) did not improve growth performance of broiler chickens, and Botsoglou et al. (2002a) and Papageorgiou et al. (2003) found that dietary supplementation of essential oils derived from oregano at levels of $50 \mathrm{or} 100 \mathrm{mg} / \mathrm{kg}$ 
in chickens, and at levels of 100 or $200 \mathrm{mg} / \mathrm{kg}$ in turkeys, respectively, had no beneficial effect on growth performance. However, other studies have shown that oregano derived essential oils, when supplemented through the drinking water at 150 or $300 \mathrm{ml} /$ ton, improved the performance of chickens (Basset, 2000; Hertrampf, 2001), and a number of studies with pigs has shown beneficial growth-promoting effects of dietary oregano essential oil (Kyriakis et al., 1998; Tsinas et al., 1998). In addition, Alcicek et al. (2003) found that dietary supplementation of an essential oil combination from six herbs including oregano, laurel, sage, myrtle, fennel and citrus improved chicken performance.

It was expected that supplementing the diet with the commercial preparation of the herbal essential oils would stimulate growth performance in broiler chickens. The observed lack of a growth-promoting effect may be associated with the composition of the basal diet and/or the environmental conditions. The diet might have contained digestible ingredients which could have inhibited bacterial growth in the intestine. Growth promoting agents could have had more impact if the diet was less digestible. In addition, wellnourished healthy chicks do not respond to growth promoting supplements when they are housed under clean, disinfected conditions and at a moderate stocking density. In the present study, the chickens were kept in a clean environment, which would probably led to a diminished efficacy of any dietary herbal additive. Consequently, little or no response would be expected under conditions conducive to a high performance, while, under conditions leading to a substandard performance, the response to dietary herbal essential oils might be more pronounced.

The effect of the dietary supplementation of the mixture of essential oils on lipid oxidation in raw breast and thigh muscle tissues is presented in Figures 1, respectively. The extent of lipid oxidation, as measured by MDA formation, differed significantly $(\mathrm{P}<0.05)$ between the dietary treatments even at zero time of refrigerated storage. All groups exhibited progressively higher $(\mathrm{P}<0.05) \mathrm{MDA}$ values on days 3,6 and 9 of storage compared to day zero.

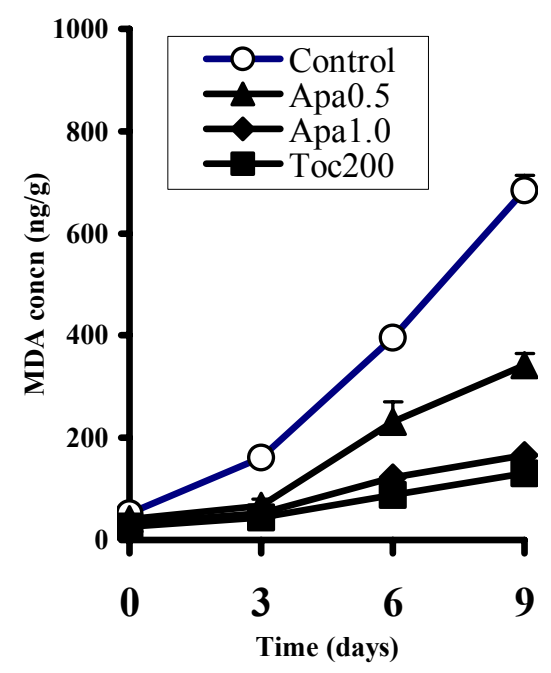

A

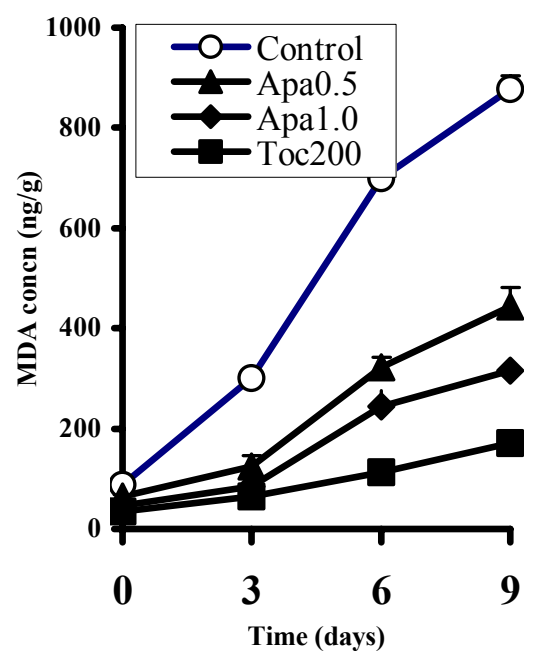

B

Figure 1 Effect of refrigerated storage on lipid oxidation (malondialdehyde, MDA, concentrations) in raw chicken breast (A) and thigh (B) muscles as a function of dietary supplementation with a mixture of herbal essential oils at levels of $0.5 \mathrm{~g} / \mathrm{kg}$ and $1.0 \mathrm{~g} / \mathrm{kg}$ compared to dietary supplementation with $200 \mathrm{mg} \alpha$ tocopheryl acetate $/ \mathrm{kg}$, and control diet. (All data points represent mean MDA concentrations from three samples and their standard deviations, some of which, however, lie within the data points)

On day zero, the raw breast samples of the control group contained a mean MDA value higher $(\mathrm{P}<$ $0.05)$ than that in the other groups. The Apa0.5 group contained a higher $(\mathrm{P}<0.05)$ MDA value than the Apa1.0 and Toc200 groups, which, in turn, did not differ $(\mathrm{P}>0.05)$ from each other (Table 3$)$. On day 3 , breast samples from the Apa0.5, Apa1.0, and Toc200 groups contained lower $(\mathrm{P}<0.05)$ MDA concentrations that the control group, and did not differ $(\mathrm{P}>0.05)$ from each other. On days 6 and 9 of storage, MDA concentrations in breast samples of the Apa0.5 group were lower $(\mathrm{P}<0.05)$ than in the control 
group, but higher $(\mathrm{P}<0.05)$ than in the Apa1.0 group, which in turn was higher $(\mathrm{P}<0.05)$ than in the Toc200 group (Figure 1).

Table 3 Malondialdehyde (MDA) concentrations in raw and heat treated breast and thigh muscle of broiler chickens on day zero of refrigerated storage, in response to dietary supplementation with either a mixture of herbal essential oils at levels of $0.5 \mathrm{~g} / \mathrm{kg}$ (Apa0.5) and $1.0 \mathrm{~g} / \mathrm{kg}$ (Apa1.0), or $200 \mathrm{mg} / \mathrm{kg} \alpha$-tocopheryl acetate (Toc200)

\begin{tabular}{ccccc}
\hline \multirow{2}{*}{ Treatments } & \multicolumn{2}{c}{ MDA concentrations, ng/g } \\
\cline { 2 - 5 } & Raw tissue & Heat treated tissue & Raw tissue & Heast muscle \\
& $88.3 \pm 3.4^{\mathrm{a}}$ & $756.6 \pm 34.6^{\mathrm{a}}$ & $52.2 \pm 6.7^{\mathrm{a}}$ & $346.0 \pm 20.6^{\mathrm{a}}$ \\
\hline Control group & $64.1 \pm 3.7^{\mathrm{b}}$ & $496.5 \pm 56.8^{\mathrm{b}}$ & $40.5 \pm 2.4^{\mathrm{b}}$ & $220.0 \pm 18.0^{\mathrm{b}}$ \\
Apa0.5 group & $46.0 \pm 3.0^{\mathrm{c}}$ & $331.6 \pm 36.8^{\mathrm{c}}$ & $32.2 \pm 1.6^{\mathrm{c}}$ & $130.5 \pm 8.4^{\mathrm{c}}$ \\
Apa1.0 group & $35.0 \pm 7.8^{\mathrm{c}}$ & $136.7 \pm 12.5^{\mathrm{d}}$ & $26.4 \pm 3.3^{\mathrm{c}}$ & $93.0 \pm 6.7^{\mathrm{d}}$ \\
Toc200 group & 3
\end{tabular}

${ }^{1}$ values are means \pm s.d. $(\mathrm{n}=3)$

a, b, c, d means in the same column with common superscripts do not differ $(\mathrm{P}>0.05)$

On day zero, the raw thigh samples of the control group contained a mean MDA value higher $(\mathrm{P}<$ 0.05) than all other groups, while the Apa0.5 group contained higher $(\mathrm{P}<0.05)$ concentrations than the Apa1.0 and Toc200 groups, which, in turn, did not differ $(\mathrm{P}>0.05)$ from each other (Table 3). On days 3, 6 and 9 of storage, the Apa0.5 group had lower $(\mathrm{P}<0.05)$ MDA concentrations than the control group, but higher $(\mathrm{P}<0.05)$ than the Apa1.0 group, which in turn were higher $(\mathrm{P}<0.05)$ than in the Toc200 group (Figure 2).

The data shown in Figure 1 suggested that the thigh muscle tended to oxidize faster than the breast muscle. The higher susceptibility of thigh muscle to oxidation has been attributed to higher absolute content of polyunsaturated fatty acids with more than two double bonds (Jensen et al., 1997). Although the breast muscle contains a higher percentage of these acids in the fat, the absolute amount in thigh muscle is three times higher than in breast muscle regardless of the dietary treatment because the total fat concentration in thigh muscle is approximately five times that of breast muscle (Jensen et al., 1997). In addition, the large amount of pro-oxidative agents originating from tissue myoglobin and other iron containing proteins found in thigh muscle may also reduce the oxidative stability in this tissue (Rhee \& Ziprin, 1987).

Whilst the MDA concentrations in the control breast and thigh muscle samples corresponded with concentrations reported by Ahn et al. (1995), Lopez-Bote et al. (1998), O'Neill et al. (1998) and Botsoglou et al, (2002b), they differed from those reported by Jensen et al. (1995) who could not detect lipid oxidation in broiler meat after a week of chilled storage. No published information could be found to compare the antioxidative effect of the present with that of other mixtures of herbal essential oils. However, several recent studies have shown that dietary supplementation of essential oils derived from rosemary and sage (Lopez-Bote et al., 1998), tea (Tang et al., 2000, 2001), and oregano has the potential to increase the oxidative stability of chicken (Botsoglou et al., 2002a; 2002b; 2003a) and turkey (Botsoglou et al., 2003 b,c; Papageorgiou et al., 2003) tissues.

The lipid oxidation profiles observed in breast and thigh muscle samples heat treated at $85{ }^{\circ} \mathrm{C}$ for 30 min prior to refrigerated storage for up to 9 days (Figures 3 and 4) were similar to the corresponding profiles of the raw samples. All heat treated groups exhibited progressively higher $(\mathrm{P}<0.05)$ MDA concentrations on days 3, 6 and 9 of storage compared to day zero. At zero time, both breast and thigh muscle samples of the Apa0.5 group contained lower $(\mathrm{P}<0.05)$ MDA concentrations than the control group, but higher $(\mathrm{P}<0.05)$ than the Apa1.0 group which, in turn, had higher $(\mathrm{P}<0.05)$ concentrations than the Toc200 group (Table 3$)$. The lipid oxidation profiles did not differ between days 3, 6 and 9 .

Comparing the lipid oxidation profiles of raw and heat treated samples, it becomes evident that the latter suffered more intense lipid oxidation during refrigerated storage than the raw samples. The heat treatment induced the lipid oxidation process as shown by the increased MDA concentrations compared to the raw samples (Figure 2 vs. Figure 1, respectively). Sheehy et al. (1993) reported that cooking increased lipid oxidation in chicken muscle tissues 4-10 fold, compared to raw tissues. Since higher concentrations of $\alpha$-tocopherol in tissues might afford better protection against oxidative attack, all raw and heat treated 
samples were submitted to $\alpha$-tocopherol analysis, the result of which is presented in Table 4 . From this data it is evident that dietary supplementation with the mixture of herbal essential oils at levels of 0.5 or 1.0 $\mathrm{mg} / \mathrm{kg}$ did not increase the concentration of $\alpha$-tocopherol in muscle tissues $(\mathrm{P}>0.05)$ compared to the control group.

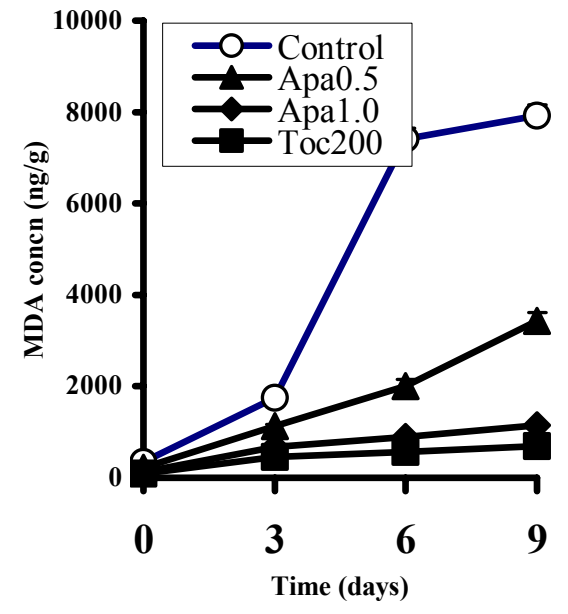

A

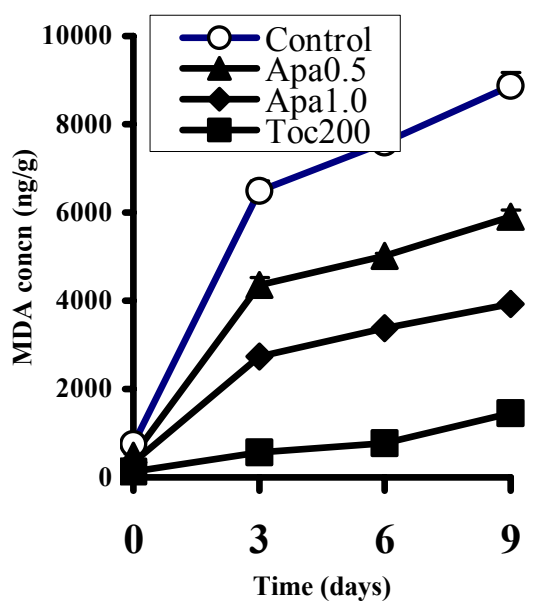

B

Figure 2 Effect of refrigerated storage on lipid oxidation (malondialdehyde, MDA, concentrations) in heat treated chicken breast (A) and thigh (B) muscles as a function of dietary supplementation with a mixture of herbal essential oils at levels of $0.5 \mathrm{~g} / \mathrm{kg}$ and $1.0 \mathrm{~g} / \mathrm{kg}$ compared to dietary supplementation with $200 \mathrm{mg} \alpha$ tocopheryl acetate $/ \mathrm{kg}$, and control diet. (All data points represent mean MDA concentrations from three samples and their standard deviations, some which lie within the data points)

Table $4 \alpha$-Tocopherol concentrations in raw and heat treated breast and thigh muscle of broiler chickens in response to dietary supplementation with either a mixture of herbal essential oils at levels of $0.5 \mathrm{~g} / \mathrm{kg}$ (Apa0.5) or $1.0 \mathrm{~g} / \mathrm{kg}$ (Apa1.0), or $200 \mathrm{mg} / \mathrm{kg} \alpha$-tocopheryl acetate (Toc200)

\begin{tabular}{ccccc}
\hline & \multicolumn{4}{c}{$\alpha$-Tocopherol concentrations, $\mu \mathrm{g} / \mathrm{g}^{1}$} \\
\cline { 2 - 5 } & Raw tissue & Heat treated tissue & Raw tissue & Breast muscle \\
& $3.86 \pm 0.44^{\mathrm{a}}$ & $3.16 \pm 0.34^{\mathrm{a}}$ & $2.12 \pm 0.18^{\mathrm{c}}$ & $1.89 \pm 0.34^{\mathrm{c}}$ \\
\hline Control group & $4.05 \pm 0.38^{\mathrm{a}}$ & $3.19 \pm 0.32^{\mathrm{a}}$ & $2.25 \pm 0.22^{\mathrm{c}}$ & $1.78 \pm 0.56^{\mathrm{c}}$ \\
Apa0.5 group & $3.98 \pm 0.22^{\mathrm{a}}$ & $3.31 \pm 0.46^{\mathrm{a}}$ & $2.32 \pm 0.28^{\mathrm{c}}$ & $1.96 \pm 0.60^{\mathrm{c}}$ \\
Apa1.0 group & $19.54 \pm 1.84^{\mathrm{b}}$ & $17.33 \pm 1.65^{\mathrm{b}}$ & $10.16 \pm 1.12^{\mathrm{d}}$ & $9.22 \pm 1.76^{\mathrm{d}}$ \\
Toc200 group & 19.22 &
\end{tabular}

${ }^{1}$ values are means \pm s.d.of three analyses performed in duplicate

$\mathrm{a}, \mathrm{b}, \mathrm{c}, \mathrm{d}$ means with common superscripts do not differ $(\mathrm{P}>0.05)$

In the control group supplemented with $30 \mathrm{mg} \alpha$-tocopheryl acetate $/ \mathrm{kg}$, the mean $\alpha$-tocopherol concentrations in the raw and heat treated thigh samples were 3.86 and $3.16 \mu \mathrm{g} / \mathrm{g}$, respectively, while mean $\alpha$-tocopherol concentrations in the raw and heat treated breast samples were 2.12 and $1.89 \mu \mathrm{g} / \mathrm{g}$, respectively. Supplementing the basal diet with $200 \mathrm{mg} \alpha$-tocopheryl acetate $/ \mathrm{kg}$ increased the levels of $\alpha$-tocopherol in the raw and heat treated thigh samples to 19.54 and $17.33 \mu \mathrm{g} / \mathrm{g}$, respectively, while mean $\alpha$-tocopherol levels in the raw and heat treated breast samples increased to 10.16 and $9.22 \mu \mathrm{g} / \mathrm{g}$, respectively. These results are in agreement with values reported for poultry (Sklan et al., 1982; Sheehy et al., 1991; Morrissey et al., 1997), pigs (Monahan et al., 1990), rabbits (Lopez-Bote et al., 1997) and beef (Liu et al., 1996). Statistical analysis showed that the concentration of $\alpha$-tocopherol in the samples was not reduced $(\mathrm{P}>0.05)$ by the heat treatment. It appears that the elevated MDA values recorded in the heat treated samples could not be attributed to a reduction of the vitamin $\mathrm{E}$ level, but to the acceleration of the oxidative processes due to 
membrane disruption and release of pro-oxidant substances (Tichivangana \& Morrissey, 1985). On the other hand, the lower MDA concentrations found in breast and thigh samples from birds supplemented with the mixture of herbal essential oils were probably the result of antioxidant components that entered the circulatory system and which were distributed and retained in the tissues, exhibiting antioxidant activity. The bioavailability of these components in chicken tissues cannot be demonstrated directly, because these components have not yet been identified nor quantified.

\section{Conclusions}

The results presented in this study showed that the mixture of herbal essential oils exerted no growth-promoting effect when incorporated in chicken diets. However, the chickens in this trial were under very little environmental or bacterial challenge. It can, therefore, not be excluded that beneficial effects of the supplement might be observed under less hygienic housing conditions and/or when using a less digestible diet. Apacox retarded lipid oxidation in both raw and heat treated breast and thigh muscles at all time points, with the supplementation level of $1.0 \mathrm{~g} / \mathrm{kg}$ diet being more effective in retarding lipid oxidation than at the $0.5 \mathrm{~g} / \mathrm{kg}$ inclusion level. The retardation afforded by Apacox was, however, inferior to that exhibited by the $\alpha$-tocopheryl acetate supplementation. Thigh muscle samples were more susceptible to oxidation than breast muscle, although the latter contained $\alpha$-tocopherol at markedly lower concentrations.

\section{References}

Abdalla, A. E. \& Roozen, J. P., 2001. The effects of stabilised extracts of sage and oregano on the oxidation of salad dressings. Eur. Food Res. Technol. 212, 551-560.

Ahn, D.U., Wolfe, F.H. \& Sim, J.S., 1995. Dietary $\alpha$-linolenic acid and mixed tocopherols, and packaging influences on lipid stability in broiler chicken breast and leg muscle. J. Food Sci. 60, 1013-1018.

Alcicek, A., Bozkurt, M. \& Cabuk, M., 2003. The effect of an essential oil combination derived from selected herbs growing wild in Turkey on broiler performance. S. Afr. J. Anim. Sci. 33, 89-94.

AOAC, 1990. Official methods of analysis (14th ed). Association of Official Analytical Chemists, Inc., Arlington, Virginia,USA,

Basset, R., 2000. Oregano positive impact on poultry production. Wld Poult., 16, 31-34.

Botsoglou, N.A., Fletouris, D.J., Papageorgiou, G.E., Vassilopoulos, V.N., Mantis, A.J. \& Trakatellis, A.G., 1994. A rapid, sensitive, and specific thiobarbituric acid method for measuring lipid peroxidation in animal tissues, food, and feedstuff samples. J. Agric. Food Chem. 42, 1931-1937.

Botsoglou, N., Fletouris, D., Psomas I. \& Mantis, A., 1998. Rapid gas chromatographic method for simultaneous determination of cholesterol and tocopherol in eggs. J. AOAC Int. 81, 1177-1183.

Botsoglou, N.A. \& Fletouris, D.J., 2001. Drug Residues in Foods. Pharmacology, Food Safety and Analysis. New York, Marcel Dekker, Inc. pp. 541-548.

Botsoglou, N.A., Florou-Paneri, P., Christaki, E., Fletouris, D.J. \& Spais, A.B., 2002a. Effect of dietary oregano essential oil on performance of chickens and on iron-induced lipid oxidation of breast, thigh and abdominal fat tissues. Br. Poult. Sci. 43, 223-230.

Botsoglou, N.A., Christaki, E., Fletouris, D.J., Florou-Paneri, P. \& Spais, A.B., 2002b. The effect of dietary oregano essential oil on lipid oxidation in raw and cooked chicken during refrigerated storage. Meat Sci. 62, 259-265.

Botsoglou, N.A., Fletouris, D.J., Florou-Paneri, P., Christaki, E. \& Spais, A.B., 2003a. Inhibition of lipid oxidation in long-term frozen stored chicken meat by dietary oregano essential oil and $\alpha$-tocopheryl acetate supplementation. Food Res. Int. 36, 207-213.

Botsoglou, N.A., Govaris, A., Botsoglou, E.N., Grigoropoulou, S.H. \& Papageorgiou, G., 2003 b. Antioxidant activity of dietary oregano essential oil and $\alpha$-tocopheryl acetate supplementation in long-term frozen stored turkey meat. J. Agric. Food Chem. 51, 2930-2936.

Botsoglou, N.A., Grigoropoulou, S.H., Botsoglou, E., Govaris, A. \& Papageorgiou, G., 2003c. The effects ofdietary oregano essential oil and $\alpha$-tocopheryl acetate on lipid oxidation in raw and cooked turkey during refrigerated storage. Meat Sci. 65, 1193-1200.

Dapkevicious, A., Venskutonis, R., Van Beek, T.A. \& Linseen, J.P.H., 1998. Antioxidant activity of extracts obtained by different isolation procedures from some aromatic herbs grown in Lithuania. J. Sci. Food Agric. 77, 140-146. 
Dorman, H.J.D. \& Deans, S.G., 2000. Antimicrobial agents from plants: antibacterial activity of plant volatile oils. J. Appl. Microbiol. 88, 308-316.

Exarchou, V., Nenadis, N., Tsimidou, M., Gerothanassis, P., Troganis, A. \& Boskou, D., 2002. Antioxidant activities and phenolic composition of extracts from greek oregano, greek sage, and summer savory. J. Agric. Food Chem. 50, 5294-5299.

Giannenas, I., Florou-Paneri, P., Papazahariadou, M., Christaki, E., Botsoglou, N.A. \& Spais, A.B., 2003. Dietary oregano essential oil supplementation on performance of broilers challenged with Eimeria tenella. Arch. Anim. Nutr. 57, 99-106.

Hammer, K.A., Carson, C.F. \& Riley, T.V., 1999. Antimicrobial activity of essential oils and other plant extracts. J. Appl. Microbiol. 86, 985-990.

Hertrampf, J.W., 2001. Alternative antibacterial performance promoters. Poult. Int. 40, 50-52.

Jensen, C., Guidera, J., Skovgaard, I.M., Staun, H. \& Skibsted, L.H., 1997. Effects of dietary $\alpha$-tocopheryl acetate supplementation on $\alpha$-tocopherol deposition in porcine $\mathrm{m}$. psoas major and $\mathrm{m}$. longissimus dorsi and on Drip loss. Color stability of pork meat. Meat Sci. 45, 491-500.

Jensen, C., Skibsted, L.H., Jakobsen, K. \& Bertelsen, G., 1995. Supplementation of broiler diets with all-rac$\alpha$ - or a mixture of natural source RRR- $\alpha-, \gamma, \delta$-tocopheryl acetate. 2 . Effect on the oxidative stability of raw and precooked broiler meat products. Poult. Sci. 74, 2048-2056.

Kyriakis, S., Sarris, K., Lekkas, S., Tsinas, A., Giannakopoulos, C., Alexopoulos, C. \& Saoulidis, C., 1998. Control of porcine proliferative enteropathy by in-feed application origanum essential oil. In: Proc. $15^{\text {th }}$ IPVS Congr., July 1998, Birmingham, UK, Vol 3, pp. 106.

Lambert, R.J.W., Skandamis, P.N., Coote, P.J. \& Nychas, G.-J.E., 2001. A study of the minimum inhibitory concentration and mode of action of oregano essential oil, thymol and carvacrol. J. Appl. Microbiol. 91, 453-462.

Lee, K-W., Everts, H., Kappert, H.J., Frehner, M., Losa, R. \& Beynen A.C., 2003. Effects of dietary essential oil components on growth performance, digestive enzymes and lipid metabolism in female broiler chickens. Br. Poult. Sci. 44, 450-457.

Liu, Q., Scheller, K.K., Arp, S.C., Schaefer, D.M. \& Frigg, M., 1996. Color coordinates for assessment of dietary vitamin E effects on beef color stability. J. Anim. Sci. 74, 106-116.

Lopez-Bote, C.J., Rey, A.I., Sanz, M., Gray, J.I. \& Buckley, D.J., 1997. Dietary vegetable oils and $\alpha$ tocopherol reduce lipid oxidation in rabbit muscle. J. Nutr. 127, 1176-1182.

Lopez-Bote, C.J., Gray, J.I., Gomaa, E.A. \& Flegal C.J., 1998. Effect of dietary administration of oil extracts from rosemary and sage on lipid oxidation in broiler meat. Br. Poult. Sci. 39, 235-240.

Monahan, F.J., Buckley, D.J., Gray, J.I. \& Morrissey, P.A., 1990 Effect of dietary vitamin E on the stability of raw and cooked pork. Meat Sci. 27, 99-108.

Morrissey, P.A., Brandon, S., Buckley, D.J., Sheehy, P.J.A. \& Frigg, M., 1997. Tissue levels of $\alpha$-tocopherol and oxidative stability of broilers supplemented with $\alpha$-tocopheryl acetate for various periods preslaughter. Br. Poult. Sci. 38, 84-88.

Nakatani, N., 1997. Herbs and spices as sources of natural antioxidants. In: Natural antioxidants chemistry: health effects and applications. Ed. Shahidi, F., AOCS Press, Champaign, IL. pp. 64-75.

O’Neill, L.M., Galvin, K., Morrissey, P.A. \& Buckley, D.J., 1998. Comparison of effects of dietary olive oil, tallow and vitamin $\mathrm{E}$ on the quality of broiler meat and meat products. Br. Poult. Sci. 39, 365-371.

Papageorgiou, G., Botsoglou, N., Govaris, A., Giannenas, I., Iliadis, S. \& Botsoglou, E., 2003. Effect of dietary oregano oil and $\alpha$-tocopheryl acetate supplementation on iron-induced lipid oxidation of turkey breast, thigh, liver and heart tissues. J. Anim. Physiol. Anim. Nutr. 87, 324-335.

Rhee, K.S. \& Ziprin, Y.A., 1987. Lipid oxidation in retail beef, pork and chicken muscles as affected by concentrations of heme pigments and nonheme iron and liposomal enzymic peroxidation activity. J. Food Biochem. 11, 1-15.

Sheehy, P.J.A., Morrisey, P.A. \& Flynn, A., 1991. Influence of dietary $\alpha$-tocopherol on $\alpha$-tocopherol concentrations in chick muscle. Br. Poult. Sci. 32, 391-397.

Sheehy, P.J.A., Morrissey, P.A. \& Fynn, A., 1993. Increased storage stability of chicken muscle by dietary $\alpha$-tocopherol supplementation. Ir. J. Agric. Food Res. 32, 67-73.

Sheehy, P.J.A., Morrisey, P.A. \& Flynn, A., 1994. Consumption of thermally-oxidised sunflower oil by chicks reduces $\alpha$-tocopherol status and increases susceptibility of tissues to lipid oxidation. Br. J. Nutr. 71, 53-65. 
Sklan, D., Bartov, I. \& Hurwitz, S., 1982. Tocopherol absorption and metabolism in the chick and turkey. J. Nutr. 112, 1394-1400.

Steel, R.G.D. \& Torrie, J.H., 1980. Principles and procedures of statistics. A biometrical approach. (2nd ed.). McGraw-Hill Book Co, New York.

Tang, S.Z., Kerry, J.P., Sheeham D., Buckley, D.J. \& Morrissey, P.A., 2000. Dietary tea catechins and ironinduced lipid oxidation in chicken meat, liver and heart. Meat Sci. 56, 285-290.

Tang, S.Z., Kerry, J.P., Sheeham D., Buckley, D.J. \& Morrissey, P.A., 2001. Antioxidative effect of dietary tea catechins on lipid oxidation of long-term frozen stored chicken meat. Meat Sci. 57, 331-336.

Tichivangana, J.Z. \& Morrissey, P.A., 1985. Metmyoglobin and inorganic metals as prooxidants in raw and cooked muscle systems. Meat Sci. 15, 107-116.

Tsimidou, M. Papavergou, E. \& Boskou, D., 1995. Evaluation of oregano antioxidant activity in mackerel oil. Food Res. Int. 28, 431-433.

Tsinas, A.C., Giannakopoulos, C.G., Papasteriades, A., Alexopoulos, C., Mavromatis, J. \& Kyriakis, S.C., 1998. Use of Origanum essential oil as growth promoter in pigs. In: Proc. $15^{\text {th }}$ IPVS Congr., July 1998, Birmingham, UK. Vol 3, pp. 221.

Ultee, A., Bennik, H.J. \& Moezelaar, R., 2002. The phenolic hydroxyl group of carvacrol is essential for action against the food borne pathogen Bacillus cereus. Appl. Envir. Microbiol. 3, 1561-1568.

Wada, S. \& Fang, X., 1992. The synergistic antioxidant effect of rosemary extract and $\alpha$-tocopherol in sardine oil model system and frozen-crushed fish meat. J. Food Proc. Preserv. 16, 263-274.

Zheng, W. \& Wang, S.Y., 2001. Antioxidant activity and phenolic compounds in selected herbs. J. Agric. Food Chem. 49, 5165-5170. 